\title{
Short-term changes in the oral microbiota of dogs after chewing different types of autoclaved bones
}

\author{
Caroline Fredrich Dourado Pinto ${ }^{1 *}$, Víviam Nunes Pignone², Alexandre Kleber Silveira ${ }^{3}$, \\ Giovane Krebs ${ }^{1}$, and Luciano Trevizan ${ }^{1}$ \\ ${ }^{1}$ Department of Animal Science, Universidade Federal do Rio Grande do Sul, Porto Alegre, \\ Rio Grande do Sul, Brazil \\ ${ }^{2}$ AllPet Odonto, Porto Alegre, Rio Grande do Sul, Brazil \\ ${ }^{3}$ Department of Biochemistry, Universidade Federal do Rio Grande do Sul, Porto Alegre, Rio Grande do Sul, Brazil
}

FREDRICH DOURADO PINTO, C., V. NUNES PIGNONE, A. KLEBER SILVEIRA, G. KREBS, L. TREVIZAN: Short-term changes in the oral microbiota of dogs after chewing different types of autoclaved bones. Vet. arhiv 91, 277-285, 2021.

\section{ABSTRACT}

The presence of dental calculus is one of the main issues associated with periodontitis in dogs. Mechanical removal of plaque and dental calculus can be performed through periodic oral prophylaxis conducted by veterinary dentists, and by continuous chewing of various items. Recent studies have demonstrated the effectiveness of bones as dental calculus agent removal in adult dogs. However, their effect regarding removal of oral microbiota remains unknown. The aim of the present study was to evaluate the effect of autoclaved spongy bone (SB) or compact bone (CB) supplementation on the oral microbiota of adult dogs with pre-existing dental calculus. The V4 region of the 16S rDNA gene was used for Illumina MiSeq next-generation sequencing. Transition was observed on the phyla proportion of the SB group, where the saliva sample initially presented a predominance of Bacteroidetes (51.3\%) and Proteobacteria (33.0\%), and changed to Proteobacteria (52.4\%) and Bacteroidetes (33.9\%). The gingival sulcus changed from Bacteroidetes $(66.7 \%)$ and Proteobacteria (17.5\%) prior to SB supplementation to Proteobacteria (76.3\%) and Bacteroidetes (18.5\%). No changes were observed in the proportion of saliva and gingival sulcus phyla in group CB. Moraxella sp. and Bergeyella zoohelcum increased in both saliva and gingival sulcus after SB supplementation. Saliva and gingival sulcus in the CB group showed increases in Porphyromonas species after 13 days' supplementation. This study showed that chewing SB had a profound impact on both saliva and gingival sulcus microbiota, while CB did not cause substantial changes in the microbiota in either environment.

Key words: oral microbiota; autoclaved beef bones; dental calculus; canine; dog

\section{Introduction}

Periodontitis is the most common oral disease in 44 to $81 \%$ of dogs from 2 years of age (KORTEGAARD et al., 2008). Supragingival

plaque and dental calculus removal resolve some of the disease-related symptoms, such as halitosis and gingivitis. As a home care alternative,

*Corresponding author:

MSc. Caroline Fredrich Dourado Pinto, Department of Animal Science, Universidade Federal do Rio Grande do Sul, Avenida Bento Gonçalves, 7712, 91540-000, Porto Alegre, Rio Grande do Sul, Brazil, E-mail: krolfredrich@hotmail.com 
supplementation with bones and dental chews has been shown to be efficient to remove supragingival plaque and dental calculus in dogs (MARX et al., 2016; QUEST, 2013). However, mechanical removal does not seem to occur in the subgingival area, where plaque-associated microorganisms, especially bacteria, degrade support structures such as the periodontal ligament and the alveolar bone. Permanent damage results in enlarged periodontal pockets, tooth mobility and, ultimately, tooth loss. Recently, the oral microbiota associated with health and periodontitis has been identified using a cultureindependent method, also known as bacterial $16 \mathrm{~S}$ rRNA gene sequencing. Bacterial species in canine plaque associated with health are mainly Gram negative, such as Porphyromonas, Bergeyella and Moraxella, whereas in disease, Gram positive anaerobic species predominate (DAVIS et al., 2013). Progression of mild periodontitis promotes a progressive reduction of aerobic Gram negative species, such as Bergeyella zoohelcum, Moraxella sp., Pasteurellaceae sp. and Neisseria shayeganii (WALLIS et al., 2015).

Although there are numerous commercial and natural products specifically formulated to prevent or reduce plaque and dental calculus, there is a lack of studies demonstrating the effects of dental chews on canine oral microbiota. A recent study evaluated the impact of dental prophylaxis on canine oral bacteria, before and after one week of the procedure. After the dental prophylaxis, supragingival plaques showed a decrease in Treponema and an increase in Moraxella and Neisseria, the genera associated with oral disease and health, respectively. While in oral microbiota, in which Psychrobacter predominated $(20 \%$ relative abundance) prior to the procedure, Pseudomonas $(80 \%$ relative abundance) were the most dominant taxon after one week (FLANCMAN et al., 2018). Accordingly, the objective of this study was to describe the effects of supplementation with autoclaved beef bones with different densities on both the gingival sulcus and oral microbiota of healthy adult Beagle dogs.

\section{Materials and methods}

Animals. Twelve healthy adult Beagles (6 males and 6 females), not neutered, 4 years old, weighing $12.7 \pm 1.67 \mathrm{~kg}$, with a body condition score (BCS) ranging from $5.3 \pm 0.4$ out of 9 points (LAFLAMME, 1997), and free of endo- and ectoparasites, were used in this study. The dogs belonged to the Animal Science Dept, Universidade Federal do Rio Grande do Sul, Porto Alegre, Brazil, and were regularly immunized and submitted for clinical and laboratory tests to measure complete blood count (CBC) and to perform biochemical and coproparasitological analyses before starting the study. The dogs were kept in individual stainless steel metabolic cages $(1.0 \times 1.0 \times 1.5 \mathrm{~m})$ equipped with a feces and urine collector, feeders and drinkers, in a temperature-controlled room at $24{ }^{\circ} \mathrm{C}$ and with a light:dark cycle of 14:10 h. They were fed twice a day with a dry complete extruded diet, free from dental additives, in order to meet their daily energy maintenance requirements (130 $\mathrm{kcal}$ of metabolizable energy $\mathrm{x}$ body weight $(\mathrm{kg})^{0.75}$ /day) as recommended by NRC (2006). Water was provided ad libitum the entire time. All dogs had large dental plaque and calculus deposition, and no professional periodontal cleaning procedure was conducted prior to this study.

Ethical approval was obtained from The Institutional Animal Care and Use Committee at the Universidade Federal do Rio Grande do Sul (protocol number 25685).

Treatments. Bovine femur, raw and fresh, was supplied from a commercial slaughterhouse that was registered and inspected according to Brazilian national laws. The bones were cut into smaller pieces, approximately $4 \mathrm{~cm}$ in length, and autoclaved under 1.0 ATM, for $30 \mathrm{~min}$, at $120^{\circ} \mathrm{C}$ (Phoenix Luferco - Araraquara, São Paulo, Brazil) to eliminate microorganisms. The treatments were: autoclaved bovine spongy bone (SB) and autoclaved bovine compact bone (CB). Autoclaved bones were stored at $-18^{\circ} \mathrm{C}$ and thawed at room temperature before being offered to the dogs, to avoid contamination. Supplementation was provided every morning after the first meal, after removal of leftovers provided the day before.

Experimental design. The experimental design was a completely randomized, consisting of 2 treatments, with 3 males and 3 female in each group, resulting in 6 replicates, as recommended 
by AAFCO (2008). The experimental period lasted 13 consecutive days, with each dog receiving one piece of autoclaved SB or CB per day for $20 \mathrm{~h}$.

Sample collection and analysis. The dogs were submitted for sample collections on days 0 and 14 , both conducted by a veterinary dentist. Before the procedures, the dogs were anesthetized $(0.03 \mathrm{mg} / \mathrm{kg}$ of acepromazine; $2 \mathrm{mg} / \mathrm{kg}$ of meperidine; $4 \mathrm{mg} / \mathrm{kg}$ of propofol and isoflurane at effect). Samples were collected from different locations. One swab was spread all over each dog's oral cavity (gums, tongue, cheeks and teeth). Another sample was collected directly from the gingival sulcus with endodontic Absorbent Paper Points \#25 (BEUTELROCK ${ }^{\circledR}$ VDW, Munich).

All samples were analyzed from the pool of samples of each group: SB - dogs supplemented with spongy bone; $\mathrm{CB}$ - dogs supplemented with compact bone. The procedures were performed at Neoprospecta Microbiome Technologies (Santa Catarina, Brazil), using the MiSeq platform (Illumina, Inc., San Diego, CA).

Prior to the high-throughput sequencing of 16S rRNA V3/V4 region, DNA enrichment and extraction were performed. In a sterile bag, an aliquot of $25 \mathrm{~g}$ of the sample was homogenized with 225 $\mathrm{g}$ of diluent, and added in a nutrient rich medium. Incubation was performed in a bacteriological oven at $35^{\circ} \mathrm{C}\left(+/-1^{\circ} \mathrm{C}\right)$ for $24 \mathrm{~h}$. DNA was obtained using a magnetic beads methodology with a proprietary protocol (Neoprospecta Microbiome Technologies, Brazil). The DNA was quantified using Qubit dsDNA BR Assay Kit (Invitrogen, USA). After quantification, the DNA was diluted to $0.5 \mathrm{ng} / \mu \mathrm{L}$. The bacteria were identified via high-throughput sequencing of the 16S rRNA V3/V4 region, using a proprietary protocol (Neoprospecta Microbiome Technologies, Brazil). The amplification of the 16S rRNA V3/V4 region was carried out using the 341F (CCTACGGGRSGCAGCAG) and 806R (GGACTACHVGGGTWTCTAAT) primers (WANG and QIAN, 2009; CAPORASO et al., 2012). The 16S rRNA libraries were sequenced using the MiSeq Sequencing System (Illumina Inc., USA) with the V2 kit, 300 Cycles, single-end sequencing. The sequences were analyzed using a proprietary pipeline (Neoprospecta Microbiome
Technologies, Brazil). Briefly, all the reads were individually submitted to a quality filter, based on the sum of the DNA base call error probability, allowing a maximum of $1 \%$ of accumulated errors. Subsequently, the DNA sequences corresponding to the Illumina adapters were removed. The resulting sequences that presented $100 \%$ identity were clustered and used for taxonomic identification, using an accurate 16S rRNA sequences database (NeoRef, Neoprospecta Microbiome Technologies, Brazil).

Statistical analysis. Qualitative and quantitative analysis of genus and species were performed according to frequency on days 0 and 14, before and after supplementation with bones, respectively, using Microsoft ${ }^{\circledR}$ Office Excel 2010.

\section{Results}

All dogs showed high acceptability of the bones, showing interest immediately after supplementation. Both types of bones had deformations after chewing, specially $\mathrm{SB}$, which was reduced to smaller pieces or totally consumed by the dogs. CB showed teeth marks and complete bone marrow removal, but remained in larger pieces compared to SB.

Analysis of the canine saliva and gingival sulcus prior to and after bone supplementation by the amplification of the $16 \mathrm{~S}$ rDNA V3/V4 region is shown in Table 1. There was a reduction in the sequence reads after SB supplementation in the saliva and gingival sulcus. In contrast, the sequence reads increased in the samples from dogs supplemented with CB.

The bacterial community was composed of ten phyla, in which more than $90 \%$ of bacteria were represented by Bacteroidetes, Proteobacteria, Fusobacteria and Firmicutes in both saliva and gingival sulcus pools, before and after bone supplementation (Figs. 1 and 2). The saliva pool sample from SB group had a majority of sequence reads of Bacteroidetes $(51.3 \%$ before vs. $33.9 \%$ after), Proteobacteria $(33.0 \%$ before vs. $52.4 \%$ after) and Fusobacteria (14.0\% before vs. $6.63 \%$ after). The CB group saliva pool had Bacteroidetes (50.0\% before vs. $53.1 \%$ after), Proteobacteria (29.4\% before vs. $30.9 \%$ after) and Fusobacteria ( $18.7 \%$ before $v s .11 .8 \%$ after) as the phyla majority. 

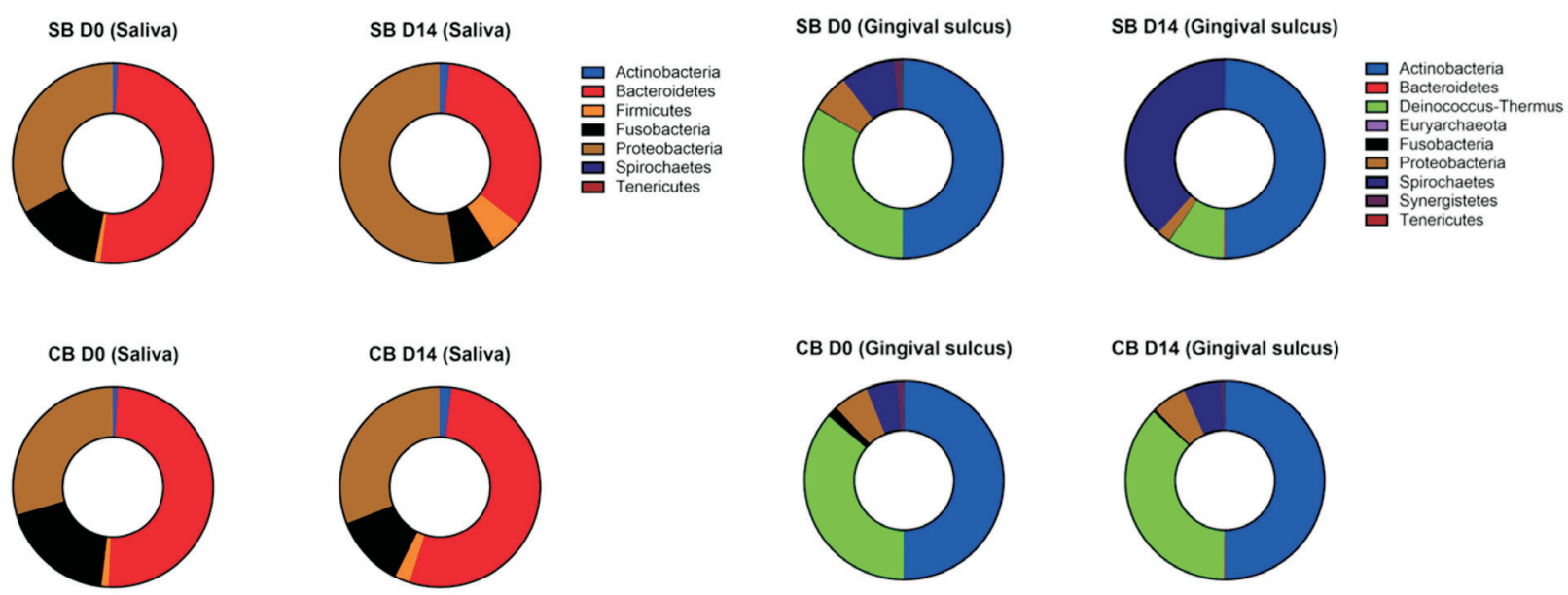

Fig. 1. Bacterial phylum identified by $16 \mathrm{~S}$ rDNA gene sequencing of saliva from adult Beagle dogs

Fig. 2. Bacterial phylum identified by $16 \mathrm{~S}$ rDNA gene sequencing of gingival sulcus from adult Beagle dogs supplemented with different autoclaved bones.

Table 1. Number of $16 \mathrm{~S}$ fragment lectures on oral samples from Beagle dogs

\begin{tabular}{|l|c|c|}
\hline & Day 0 & Day 14 \\
\hline & \multicolumn{2}{|c|}{ Saliva } \\
\hline Spongy bone & 58328 & 47729 \\
\hline Compact bone & 56608 & 65707 \\
\hline & \multicolumn{2}{|c|}{ Gingival sulcus } \\
\hline Spongy bone & $61943 \quad$ & 40568 \\
\hline Compact bone & 62719 & 93396 \\
\hline
\end{tabular}

Table 2. Representative bacterial species identified by $16 \mathrm{~S}$ rDNA gene sequencing present in the saliva population from adult Beagle dogs supplemented with different autoclaved bones

\begin{tabular}{|c|c|c|c|c|}
\hline Species & SB D0 & SB D14 & CB D0 & CB D14 \\
\hline & \multicolumn{4}{|c|}{ OTU $(\%$ of total $)$} \\
\hline Bergeyella zoohelcum ${ }^{1}$ & $4631(7.94)$ & $6447(13.5)$ & $2532(4.47)$ & $3078(4.68)$ \\
\hline Capnocytophaga cynodegmi ${ }^{1}$ & $665(1.14)$ & $311(0.65)$ & $629(1.11)$ & $828(1.26)$ \\
\hline Conchiformibius steedae ${ }^{2}$ & $2062(3.54)$ & $1405(2.94)$ & $1235(2.18)$ & $603(0.92)$ \\
\hline Fusobacterium nucleatum $^{3}$ & $1683(2.89)$ & $288(0.60)$ & $2652(4.68)$ & $324(0.49)$ \\
\hline Fusobacterium russii ${ }^{3}$ & $6384(10.9)$ & $2657(5.57)$ & $7828(13.8)$ & $7250(11.03)$ \\
\hline Moraxella canis ${ }^{2}$ & $1359(2.33)$ & $829(1.74)$ & $825(1.46)$ & $1030(1.57)$ \\
\hline Moraxella lacunata ${ }^{2}$ & $322(0.55)$ & $770(1.61)$ & $307(0.54)$ & $959(1.46)$ \\
\hline Moraxella sp. $^{2}$ & $11275(19.3)$ & $16769(35.1)$ & $12116(21.4)$ & $12646(19.3)$ \\
\hline Neisseria shayeganii ${ }^{2}$ & $1010(1.73)$ & $504(1.06)$ & $472(0.83)$ & $396(0.60)$ \\
\hline Neisseria weaveri ${ }^{2}$ & $539(0.92)$ & $1238(2.59)$ & $276(0.49)$ & $2601(3.96)$ \\
\hline
\end{tabular}

SB D0 - spongy bone group day 0; SB D14 - spongy bone group day 14; CB D0 - compact bone group day 0; CB D14 - compact bone group day 14; OTU - operational taxonomic units; ${ }^{1}$ - Bacteroidetes; ${ }^{2}$ - Proteobacteria; ${ }^{3}$ - Fusobacteria; ${ }^{4}$ - Firmicutes 
C. Fredrich Dourado Pinto et al.: Chewing bones change the oral microbiota of dogs

Table 2. Representative bacterial species identified by $16 \mathrm{~S}$ rDNA gene sequencing present in the saliva population from adult Beagle dogs supplemented with different autoclaved bones (continued)

\begin{tabular}{|c|c|c|c|c|}
\hline Species & SB D0 & SB D14 & CB D0 & CB D14 \\
\hline & \multicolumn{4}{|c|}{ OTU ( $\%$ of total) } \\
\hline Neisseria zoodegmatis $^{2}$ & $499(0.86)$ & $1586(3.32)$ & $164(0.29)$ & $305(0.46)$ \\
\hline Pasteurella canis ${ }^{2}$ & $708(1.21)$ & $269(0.56)$ & $173(0.31)$ & $379(0.58)$ \\
\hline Pasteurella dagmatis ${ }^{2}$ & $578(0.99)$ & $718(1.50)$ & $397(0.70)$ & $975(1.48)$ \\
\hline Porphyromonas cangingivalis ${ }^{1}$ & $10602(18.2)$ & $6838(14.3)$ & $10147(17.9)$ & $16691(25.4)$ \\
\hline Porphyromonas canoris ${ }^{1}$ & $4879(8.36)$ & $997(2.09)$ & $6454(11.4)$ & $4518(6.88)$ \\
\hline Porphyromonas gingivicanis ${ }^{1}$ & $773(1.33)$ & $496(1.04)$ & $1229(2.17)$ & $1572(2.39)$ \\
\hline Porphyromonas gulae ${ }^{1}$ & $6275(10.8)$ & $656(1.37)$ & $4607(8.14)$ & $7216(11.0)$ \\
\hline Porphyromonas macacae ${ }^{1}$ & $889(1.52)$ & $78(0.16)$ & $1532(2.71)$ & $153(0.23)$ \\
\hline Streptococcus fryi ${ }^{4}$ & $109(0.19)$ & $1365(2.86)$ & $102(0.18)$ & $453(0.69)$ \\
\hline Streptococcus minor ${ }^{4}$ & $72(0.12)$ & $902(1.89)$ & $158(0.28)$ & $557(0.85)$ \\
\hline Tannerella forsythia ${ }^{1}$ & $442(0.76)$ & $66(0.14)$ & $564(1.00)$ & $305(0.46)$ \\
\hline
\end{tabular}

SB D0 - spongy bone group day 0; SB D14 - spongy bone group day 14; CB D0 - compact bone group day 0; CB D14 - compact bone group day 14; OTU - operational taxonomic units; ${ }^{1}$ - Bacteroidetes; ${ }^{2}$ - Proteobacteria; ${ }^{3}$ - Fusobacteria; ${ }^{4}$ - Firmicutes

Table 3. Representative bacterial species identified by $16 \mathrm{~S}$ rDNA gene sequencing present in the gingival sulcus population from adult Beagle dogs supplemented with different autoclaved bones

\begin{tabular}{|c|c|c|c|c|}
\hline Species & SB D0 & SB D14 & CB D0 & CB D14 \\
\hline & \multicolumn{4}{|c|}{ OTU ( $\%$ of total) } \\
\hline Arcobacter thereius $^{1}$ & $872(1.41)$ & $102(0.25)$ & $642(1.02)$ & $292(0.31)$ \\
\hline Bergeyella zoohelcum $^{2}$ & $342(0.55)$ & $1750(4.31)$ & $70(0.11)$ & $96(0.10)$ \\
\hline Campylobacter rectus $^{1}$ & $5672(9.16)$ & $289(0.71)$ & $2409(3.84)$ & $3623(3.88)$ \\
\hline Conchiformibius steedae ${ }^{1}$ & $366(0.59)$ & $767(1.89)$ & $264(0.42)$ & $365(0.39)$ \\
\hline Filifactor villosus ${ }^{3}$ & $199(0.32)$ & $15(0.04)$ & $992(1.58)$ & $665(0.71)$ \\
\hline Fusobacterium nucleatum ${ }^{4}$ & $1901(3.07)$ & $19(0.05)$ & $5229(8.34)$ & $554(0.59)$ \\
\hline Fusobacterium russii ${ }^{4}$ & $5602(9.04)$ & $1525(3.76)$ & $1998(3.19)$ & $9855(10.6)$ \\
\hline Moraxella sp. ${ }^{1}$ & $1959(3.16)$ & $25614(63.1)$ & $1668(2.66)$ & $3144(3.37)$ \\
\hline Neisseria canis $^{1}$ & $60(0.10)$ & $21(0.05)$ & $27(0.04)$ & $2197(2.35)$ \\
\hline Neisseria weaveri $^{1}$ & $31(0.05)$ & $460(1.13)$ & $35(0.06)$ & $194(0.21)$ \\
\hline Pasteurella dagmatis ${ }^{1}$ & $232(0.37)$ & $2220(5.47)$ & $91(0.15)$ & $299(0.32)$ \\
\hline Porphyromonas cangingivalis $^{2}$ & $11026(17.8)$ & $4906(12.1)$ & $10541(16.8)$ & $33010(35.3)$ \\
\hline Porphyromonas canoris ${ }^{2}$ & $12023(19.4)$ & $186(0.46)$ & $2612(4.16)$ & $8176(8.75)$ \\
\hline Porphyromonas crevioricanis ${ }^{2}$ & $1020(1.65)$ & $8(0.02)$ & $2800(4.46)$ & $121(0.13)$ \\
\hline Porphyromonas gingivicanis ${ }^{2}$ & $1250(2.02)$ & $239(0.59)$ & $1796(2.86)$ & $2652(2.84)$ \\
\hline Porphyromonas gulae $^{2}$ & $13607(22.0)$ & $76(0.19)$ & $9820(15.7)$ & $23473(25.1)$ \\
\hline Porphyromonas macacae ${ }^{2}$ & $846(1.37)$ & $3(0.01)$ & $15861(25.3)$ & $209(0.22)$ \\
\hline Tannerella forsythia ${ }^{2}$ & $408(0.66)$ & $38(0.09)$ & $668(1.06)$ & $976(1.04)$ \\
\hline Treponema denticola ${ }^{5}$ & $1365(2.20)$ & $5(0.01)$ & $1169(1.86)$ & $903(0.97)$ \\
\hline
\end{tabular}

SB D0 - spongy bone group day 0; SB D14 - spongy bone group day 14; CB D0 - compact bone group day 0; CB D14 - compact bone group day 14; OTU - operational taxonomic units; ${ }^{1}$ - Proteobacteria ${ }^{2}$ - Bacteroidetes; 3 , Firmicutes; ${ }^{4}$ - Fusobacteria; ${ }^{5}$ - Spirochaetes 
C. Fredrich Dourado Pinto et al.: Chewing bones change the oral microbiota of dogs

Table 4. Shannon's diversity index of oral samples from Beagle dogs supplemented with different types of bones

\begin{tabular}{|l|c|c|}
\hline & Day 0 & Day 14 \\
\hline & \multicolumn{2}{|c|}{ Saliva* } \\
\hline Spongy bone & $3.509(656)$ & $3.416(509)$ \\
\hline Compact bone & $3.509(699)$ & \multicolumn{2}{|c|}{ Gingival sulcus* } \\
\hline & & \\
\hline Spongy bone & $3.223(653)$ & $2.501(355)$ \\
\hline Compact bone & $3.185(559)$ & $2.95(533)$ \\
\hline
\end{tabular}

*Shannon's diversity index (number of species identified)

The gingival sulcus pool sample from the SB group had a majority of sequence reads from Bacteroidetes $(66.7 \%$ before vs. $18.5 \%$ after), Proteobacteria (17.5\% before vs. $76.3 \%$ after) and Fusobacteria (12.1\% before vs. $4.20 \%$ after). The CB group saliva pool had Bacteroidetes $(72.3 \%$ before vs. $74.0 \%$ after), Proteobacteria $(10.1 \%$ before vs. $12.2 \%$ after) and Fusobacteria (11.6\% before $v s .11 .2 \%$ after) as the phyla majority.

Prior to supplementation with SB, Porphyromonas (40.2\%), Moraxella $(22.2 \%)$ and Fusobacterium (13.8\%) were the most abundant genus in the saliva (Table 2). There was a change in the saliva composition after SB supplementation, in which Moraxella (38.5\%), Porphyromonas (19.0\%) and Bergeyella (13.5\%) Predominated. The genus composition in the saliva from CB group did not change during the experimental period, with Porphyromonas $(42.3 \%$ before vs. $45.9 \%$ after) being the most abundant, followed by Moraxella (23.4\% before vs. $22.3 \%$ after) and Fusobacterium (18.5\% before $v s .11 .5 \%$ after).

Health associated species, Moraxella sp. and Bergeyella zoohelcum, increased in the saliva after SB supplementation. However, with $\mathrm{CB}$ supplementation there was an increase in Porphyromonas cangingivalis and Porphyromonas gulae species.

Porphyromonas (64.2\%), Fusobacterium (12.1\%) and Campylobacter (9.16\%) were the most abundant genus in the gingival sulcus before SB supplementation (Table 3). After SB supplementation, the genus composition changed to Moraxella (63.1\%), Porphyromonas (13.4\%), Pasteurella (5.47\%) and Bergeyella (4.31\%). As in the saliva, no changes to genus composition were observed in the gingival sulcus from the CB group before and after supplementation, with Porphyromonas $(69.3 \%$ before vs. $72.3 \%$ after) being the most abundant, followed by Fusobacterium (11.5\% before vs. $11.2 \%$ after) and Campylobacter (3.84\% before vs. 3.88\% after).

Moraxella sp., Pasteurella dagmatis and Bergeyella zoohelcum increased in gingival sulcus after SB supplementation. The most abundant increases after CB included Porphyromonas cangingivalis, Porphyromonas gulae, Fusobacterium russii, Porphyromonas canoris and Neisseria canis.

There was a reduction in Shannon's diversity index in both environments, saliva and gingival sulcus, after $\mathrm{SB}$ and $\mathrm{CB}$ supplementation (Table 4). A higher decrease was observed in the gingival sulcus from the SB group.

\section{Discussion}

The aim of the present study was to evaluate the effect of supplementation bones of different densities on the oral microbiota of healthy adult dogs. A recent study showed that dogs supplemented with a raw bovine femur had effective dental calculus reduction, especially those that received spongy bones (MARX et al., 2016). However, the contamination risk by Salmonella is a major concern for animal and human health. As a result, we formulated a hypothesis that consuming an autoclaved bovine femur would promote a similar 
effect on dental calculus removal, and also impact positively on the canine oral microbiota. Research focusing on the canine oral microbiota has been conducted due to the diversity of systemic diseases associated with periodontitis, such as kidney, myocardium and liver disorders (PAVLICA et al., 2008). For this reason, it would be interesting to find a dental chew that is able to reduce the pathogenic bacteria during the interval between periodontal cleanings.

Prior to supplementation, the most abundant phylum in both the saliva and gingival sulcus were Bacteroidetes, Proteobacteria and Fusobacteria. These findings are similar to those demonstrated by STURGEON et al. (2013) in clinically healthy dogs. After 13 days, the group supplemented with SB showed modification of the quantity of phylum in the saliva and gingival sulcus, with an increase in Proteobacteria, followed by Bacteroidetes and Fusobacteria. This finding is consistent with another survey in which dental plaque from healthy dogs also had a higher abundance of Proteobacteria and Bacteroidetes (DAVIS et al., 2013). In contrast, even after supplementation, the CB group did not present any changes to the amount of phylum.

Samples from both environments, saliva and gingival sulcus, presented a higher proportion of Gram negative bacteria before and after bone supplementation. Gram negative bacteria are related to health, while Gram positive are abundant in periodontitis, which may be due to environmental changes, such as nutrient and oxygen sources, $\mathrm{pH}$ and immunological status (DAVIS et al., 2013). The dogs used in this study had abundant plaque and dental calculus deposits before the experiment started, but none had severe periodontitis.

Porphyromonas was the most predominant genus in both saliva and gingival sulcus prior to supplementation. Several studies have identified Porphyromonas in both healthy and sick dogs, which highlights its opportunistic and adaptative nature (DAVIS et al., 2013; STURGEON et al., 2013; WALLIS et al., 2015). As observed by STURGEON et al. (2013), Fusobacterium was the second most abundant genus after Porphyromonas. This genus is associated with co-aggregation in human dental plaque (KOLENBRANDER et al., 1989). The SB group had a greater decrease in Porphyromonas, Fusobacterium, Tannerella and Treponema, all bacteria associated with periodontitis (FLANCMAN et al., 2018).

Dental calculus reduction promoted by SB supplementation had a major impact on both the saliva and gingival sulcus, with a pronounced increase in Moraxella sp. and Bergeyella zoohelcum, species related to healthy and early dental plaque (STURGEON et al., 2013; HOLCOMBE et al., 2014; WALLIS et al., 2015). This suggests that SB chewing for 13 days was capable of modifying the oral microbiota profile, previously abundant in disease associated bacteria, to healthy bacteria.

$\mathrm{CB}$ supplementation was not effective in changing the relative abundance in either saliva or gingival sulcus. Porphyromonas cangingivalis, Porphyromonas gulae, Porphyromonas canoris, Fusobacterium russii and Neisseria canis predominated after 13 days of CB supplementation. Except for Neisseria canis, the other species are related to mild and severe periodontitis, given their anaerobic and opportunistic characteristics that prosper in the anaerobic environment of inflammation (DAVIS et al., 2013).

The diversity of the microbiota in the saliva and gingival sulcus were reduced after SB and $\mathrm{CB}$ supplementation. These results corroborate with FLANCMAN et al. (2018), who found that canine dental plaque presented greater richness and diversity compared to samples collected after dental prophylaxis. It is known that mild and disease stages of periodontitis create a highly specialized environment within the oral cavity, and only adapted microorganisms are able to remain and predominate under these conditions.

The expressed effect of SB on both the saliva and gingival sulcus microbiota may be explained by the physical characteristics of the bone, mainly its texture and porous structure. As reported by MARX et al. (2016), SB are more efficient in reducing dental calculus because they allow the teeth to penetrate into the bone matrix, thus increasing the surface area between tooth and bone. Since dental calculus consists of mineralized calcium carbonates and phosphates over pre-existing plaque, only 
mechanical abrasion is effective to remove hard deposits. In contrast, the hardness of $\mathrm{CB}$ does not allow the same tooth-bone contact as SB, thus the mechanical removal of dental calculus is decreased, which directly impacts the oral microbiota.

Although bone supplementation has positive aspects regarding dental plaque and calculus, previous studies have shown the incidence of chocking, visceral perforation, and esophageal and intestinal concretion due to bone consumption (ROUSSEAU et al., 2007; GIANELLA et al., 2009; JUVET et al., 2010; THOMPSON et al., 2012). However, a recent study demonstrated that adult Beagle dogs had no lesions or teeth root and enamel fractures, or esophageal or intestinal obstructions after autoclaved beef bone consumption for 13 days (PINTO et al., 2020). However, some gingival lesions and bone remnants were noted in the group of dogs that consumed SB, which provides a negative aspect to this item.

Autoclaved SB showed itself to be an interesting dental chew item, given its strong ability to change supragingival and subgingival microbiota. Dental prophylaxis must be performed once a year, but during this interval SB could be used as a home oral care item by dog owners. To the authors' knowledge, this is one of the few studies to evaluate the effect of continuous autoclaved bone supplementation on the canine oral microbiota. However, our small sample size and lack of replications were limiting factors in this research.

\section{Conclusions}

Although there are certain reservations about the safety of bones as chewing items, previous studies have demonstrated that specific bones are effective in reducing dental calculus in adult Beagle dogs. As expected, the higher dental calculus removal promoted by SB also had a positive impact on the canine oral microbiota, by increasing the relative abundance of health-associated bacteria in both the saliva and gingival sulcus. Autoclaved spongy bones could play an important role as home oral care products used between periodontal prophylaxis intervals, due their capacity for reducing both dental calculus and pathogenic bacteria in the canine oral cavity.

\section{Acknowledgement}

The authors are thankful for the financial support given by the Brazilian governmental research support institution Coordenação de Aperfeiçoamento de Pessoal de Nível Superior-CAPES.

\section{References}

AAFCO - Association of American Feed Control Officials (2008): Official publication. Champaign, IL, USA.

CAPORASO, J. G., C. L. LAUBER, W. A. WALTERS, D. BERG-LYONS, J. HUNTLEY, N. FIERER, S. M. OWENS, J. BETLEY, L. FRASER, M. BAUER, N. GORMLEY, J. A. GILBERT, G. SMITH, R. KNIGHT (2012): Ultra-highthroughput microbial community analysis on the Illumina HiSeq and MiSeq platforms. ISME. 6, 1621-1624.

DOI: 10.1038/ismej.2012.8

DAVIS, I. J., C. WALLIS, O. DEUSCH, A. COLYER, L. MILELLA, N. LOMAN, S. HARRIS (2013): A crosssectional survey of bacterial species in plaque form client owned dogs with healthy gingiva, gingivitis or mild periodontitis. PLoS One. 8, 1-12.

DOI: $10.1371 /$ journal.pone. 0083158

FLANCMAN, R., A. SINGH, J. S. WEESE (2018): Evaluation of the impact of dental prophylaxis on the oral microbiota of dogs. PLoS One. 13, 1-18.

DOI: 10.1371/journal.pone.0199676

GIANELLA, P., N. S. PFAMMATER, I. A. BURGENER (2009): Oesophageal and gastric endoscopic foreign body removal: Complications and follow-up of 102 dogs. J Small Anim Pract. 50, 649-654.

DOI: 10.1111/j.1748-5827.2009.00845.x PMID: 19954441

HOLCOMBE, L. J., N. PATEL, A. COLYER, O. DEUSCH, C. O'FLYNN, S. HARRIS (2014): Early canine plaque biofilms: characterization of key bacterial interactions involved in initial colonization of enamel. PLoS One. 9, 1-24.

DOI: 10.1371/journal.pone.0113744

JUVET, F., M. PINILLA, R. E. SCHIEL, C. T. MOONEY (2010): Oesophageal foreign bodies in dogs: factors affecting success of endoscopic retrieval. Ir. Vet. J. 63, $163-168$.

DOI: $10.1186 \% 2$ F2046-0481-63-3-163

KOLENBRANDER, P., R. ANDERSEN, L. MOORE (1989): Coaggregation of Fusobacterium nucleatum, Selenomonas flueggei, Selenomonas infelix, Selenomonas noxia, and Selenomonas sputigena with strains from 11 genera of oral bacteria. Infect Immun. 57, 3194-3203.

KORTEGAARD, H. E., T. ERIKSEN, V. BAELUM (2008): Periodontal disease in research beagle dogs - an epidemiological study. J. Small Anim. Pract. 49, 610-616. DOI: 10.1111/j.1748-5827.2008.00609.x 
LAFLAMME, D. R. P. C. (1997): Development and validation of a body condition score system for dogs: A clinical tool. Canine Pract. 22, 10-15.

MARX, F. R., G. S. MACHADO, J. G. PEZZALI, C. S. MARCOLLA, A. M. KESSLER, Ø. AHLSTRØM, L. TREVIZAN (2016): Raw beef bones as chewing items to reduce dental calculus in Beagle dogs. Aust. Vet. J. 94, 1823.

DOI: $10.1111 /$ avj.12394

NRC - National Research Council (2006): Nutrient requirements of dogs and cats. National Academies Press, Washington, DC, USA.

PAVLICA, Z., M. PETELIN, P. JUNTES, D. ERZEN, D. A. CROSSLEY, U. SKALERIC (2008): Periodontal disease burden and pathological changes in organs of dogs. J. Vet. Dent. 25, 97-105.

DOI: $10.1177 / 089875640802500210$

PINTO, C. F. D., W. LEHR, V. N. PIGNONE, C. P. CHAIN, L. TREVIZAN (2020): Evaluation of teeth injuries in Beagle dogs caused by autoclaved beef bones used as a chewing item to remove dental calculus. PLoS One. 13, 1-15.

DOI: 10.1371/journal.pone.0228146

QUEST, B.W. (2013): Oral health benefits of a daily dental chew in dogs. J. Vet. Dent. 30, 84-87.

DOI: $10.1177 / 089875641303000203$
ROUSSEAU, A., J. PRITTIE, J. D. BROUSSARD, P. R. FOX, J. HOSKINSON (2007): Incidence and characterization of esophagitis following esophageal foreign body removal in dogs: 60 cases (1999-2003). J. Vet. Emerg. Crit. Care 17, 159-163.

DOI: $10.1111 / \mathrm{j} .1476-4431.2007 .00227 . \mathrm{x}$

STURGEON, A., J. W. STULL, M. C. COSTA, J. S. WEESE (2013): Metagenomic analysis of the canine oral cavity as revealed by high-throughput pyrosequencing of the $16 \mathrm{~S}$ rRNA gene. Vet. Microbiol. 162, 891-898.

DOI: $10.1016 /$ j.vetmic.2012.11.018

THOMPSON, H. C., Y. CORTES, K. GANNON, D. BAILEY, S. FREER (2012): Esophageal foreign bodies in dogs: 34 cases (2004-2009). J. Vet. Emerg. Crit. Care 22, 253-261.

DOI: 10.1111/j.1476-4431.2011.00700.x

WALLIS, C., M. MARSHALL, A. COLYER, C. O'FLYNN, O. DEUSCH, S. HARRIS (2015): A longitudinal assessment of changes in bacterial community composition associated with the development of periodontal disease in dogs. Vet. Microbiol. 181, 271-282.

DOI: 10.1016/j.vetmic.2015.09.003

WANG, Y., P-Y. QIAN (2009): Conservative fragments in bacterial 16S rRNA genes and primer design for $16 \mathrm{~S}$ ribosomal DNA amplicons in metagenomics studies. PLoS ONE. 4, 1-9.

DOI: 10.1371/journal.pone.0007401

Received: 28 March 2020

Accepted: 23 June 2020

FREDRICH DOURADO PINTO, C., V. NUNES PIGNONE, A. KLEBER SILVEIRA, G. KREBS, L. TREVIZAN: Kratkotrajne promjene u mikrobioti usne šupljine pasa nakon žvakanja različitih vrsta autoklaviranih kostiju. Vet. arhiv 91, 277-285, 2021.

\section{SAŽETAK}

Zubni kamenac među glavnim je uzrocima koji se povezuju s periodontitisom u pasa. Mehaničko uklanjanje plaka i zubnog kamenca može se provesti redovitom oralnom profilaksom kod veterinara stomatologa i kontinuiranim žvakanjem određenih predmeta. Najnovija istraživanja pokazuju učinkovitost kostiju pri uklanjanju zubnog kamenca u odraslih pasa. Način na koji se zubni kamenac pritom uklanja ostaje nepoznat. Cilj je ovoga rada bio istražiti učinak dodatka autoklaviranih spužvastih kostiju (SB) i čvrstih kostiju (CB) na oralnu mikrobiotu odraslih pasa sa zubnim kamencem. Za Illumina MiSeq sekvenciranje sljedeće generacije upotrijebljena je regija V4 gena 16S rDNA. Promatrana je promjena udjela pojedinih taksonomskih kategorija bakterija na razini phyla u skupini SB. U uzorcima sline inicijalno je utvrđena dominacija Bacteroidetes $(51,3 \%)$ i Proteobacteria $(33,0 \%)$ te promjene za Proteobacteria $(52,4 \%)$ i za Bacteroidetes (33,9\%). Zahvaljujući dodatku SB-a žlijeb desni promijenio je bakterijski sastav od Bacteroidetes (66,7 \%) i Proteobacteria $(17,5 \%)$ na Proteobacteria $(76,3 \%)$ i Bacteroidetes $(18,5 \%)$. U skupini (CB) nisu uočene promjene u phyla kategorijama sline i žlijeba desni. Nakon dodavanja SB-a koncentracija bakterija Moraxella sp. i Bergeyella zoohelcum porasla je i u slini i u žlijebu desni. Slina i žlijeb desni u (CB) skupini pokazali su porast vrste Porphyromonas nakon 13 dana primjene. Ovo je istraživanje pokazalo da žvakanje spužvastih kosti znatno utječe na mikrobiotu i sline i žlijeba desni, dok u pasa koji su žvakali čvrste kosti bitnih promjena nije bilo.

Ključne riječi: oralna mikrobiota; autoklavirane goveđe kosti; zubni kamenac; pas 
